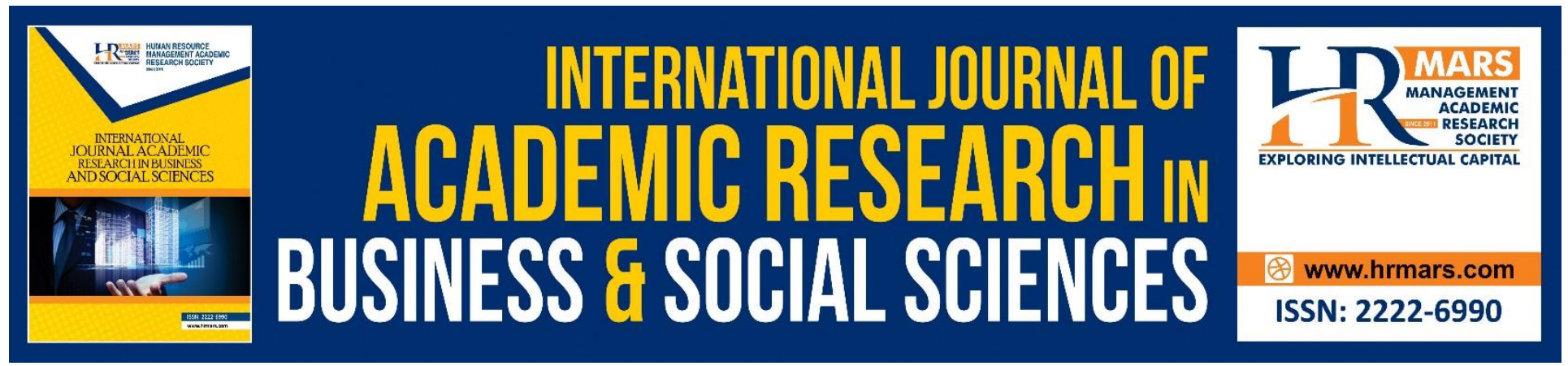

\title{
The Development of Housing Model Constructs to Measure the Well-Being of the Residents in Peri Urban Area of Klang- Langat Valley Extended Metropolitan Region, Malaysia
}

Yazid Saleh, Hanifah Mahat, Mohmadisa Hashim, Nasir Nayan, Samsudin Suhaili \& Irfan Azim Mohd Zanuddin

To Link this Article: http://dx.doi.org/10.6007/IJARBSS/v8-i8/4629

DOI: $\quad 10.6007 /$ IJARBSS/v8-i8/4629

Received: 22 June 2018, Revised: 30 July 2018, Accepted: 30 August 2018

Published Online: 08 September 2018

In-Text Citation: (Saleh et al., 2018)

To Cite this Article: Saleh, Y., Mahat, H., Hashim, M., Nayan, N., Suhaili, S., \& Zanuddin, I. A. M. (2018). The Development of Housing Model Constructs to Measure the Well-Being of the Residents in Peri Urban Area of Klang-Langat Valley Extended Metropolitan Region, Malaysia. International Journal of Academic Research in Business and Social Sciences, 8(8), 738-755.

\section{Copyright: (C) 2018 The Author(s)}

Published by Human Resource Management Academic Research Society (www.hrmars.com)

This article is published under the Creative Commons Attribution (CC BY 4.0) license. Anyone may reproduce, distribute, translate and create derivative works of this article (for both commercial and non-commercial purposes), subject to full attribution to the original publication and authors. The full terms of this license may be seen

at: http://creativecommons.org/licences/by/4.0/legalcode

\section{Vol. 8, No. 8, August 2018, Pg. 738 - 755}




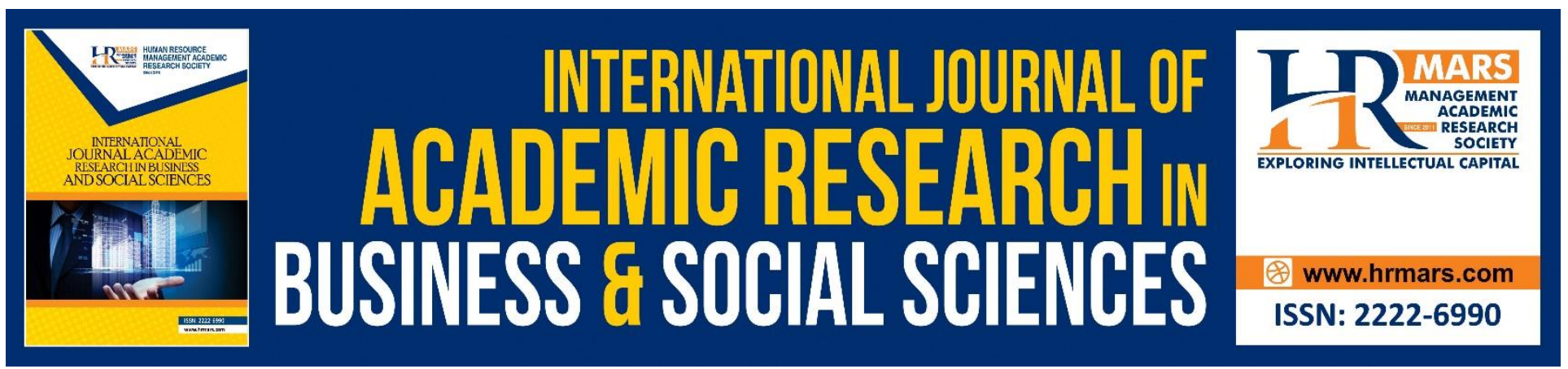

\title{
The Development of Housing Model Constructs to Measure the Well-Being of the Residents in Peri Urban Area of Klang-Langat Valley Extended Metropolitan Region, Malaysia
}

\author{
Yazid Saleh, Hanifah Mahat, Mohmadisa Hashim, Nasir Nayan, \\ Samsudin Suhaili \& Irfan Azim Mohd Zanuddin \\ Department of Geography \& Environment, Faculty of Human Sciences, Sultan Idris Education \\ University, 35900 Tanjong Malim, Perak, Malaysia. \\ Email:yazid@fsk.upsi.edu.my
}

\begin{abstract}
This article aims to develop and analyse a model for the well-being of the people living in the peri urban area based on the housing constructs. A total of 1000 respondents consisting of heads of household living in the Extended Metropolitan Region (EMR) of the Klang -Langat Valley were randomly selected as the study samples. The data were analysed using the exploratory factor analysis (EFA) method, confirmatory factor analysis (CFA) and structural equation modelling (SEM). The findings showed that only three sub-constructs (i) facilities, (ii) area selection, and (iii) security out of nine items of housing constructs with high validity values in which the CR exceeded 0.7. These findings showed that the measurement model built met the measurement criteria for measuring the well-being of the suburbs. The implication of this study is an important opportunity for people living in the rural areas as it plays role in improving their living standards. The growth in the housing aspect shows a positive growth for the development of the suburban areas in ensuring people's well-being. Keywords: Well-Being, Housing, Suburbs, Transformation
\end{abstract}

Introduction

Transformation process is rapidly growing around the metropolitan areas of Southeast Asia. Urban transformation has formed a settlement pattern in the extended metropolitan region (EMR) in most countries such as Singapore, Malaysia, and Indonesia. According to Jones (2014), the most rapid transformation process in Malaysia is in Kuala Lumpur and has spread to its fringe areas like Selangor and other suburbs including Klang Valley. Transformation is a changing process and application of urban features towards an area and this process involves migration of rural populations, changes in economic activity, development of urban area, increased urban facilities, changes in social, value and 
character of traditional societies to modern societies, and changes in land use (The Second National Urbanisation Policy, 2016). The transformation process occurred has gradually forced the spreading to the suburban area (Samruhaizad, 2015) as the central area is already crowded. In general, there are several indicators that can be applied to illustrate the transformation that happened, namely changes in land use, transportation, infrastructure, socioeconomics and population (Christiaensen, Weerdt, \& Todo, 2013; Katiman, 2006b; Shaharudin, Lim, \& Abdul Samad, 2004; Wan Maznah, Rosniza Aznie, \& Azahan, 2016).

Transformation and urbanisation are commonly used to describe the changes of a certain area. According to Friedman and Wulff (1986), urbanisation refers to the concentration of populations towards some settlements where all major economic activities such as trade and services are carried out. This is supported by Webster (2002), which explains that an area will become more complex with economic, social and physical activities. This process exists as a result of human actions towards the surrounding environment which causes the emergence of urban area resulted from the evolutionary process which will change the patterns of settlement, neighbourhood and well-being of the populations in a country, especially developing countries such as Malaysia.

Katiman (2006b) has proven that the influence of globalisation has a major impact on the urbanisation in Malaysia especially in the EMR Klang-Langat Valley. Even though the city boundary has not changed but the implications and influences of this urbanisation can be seen spreading to Hulu Selangor and Kuala Langat. In the past, the development of rural areas was more traditional and labelled as poor areas (Haryati \& Nurasyikin, 2013;Yahaya, 2002 ). However, this fringe area is important for the people living in the transitional zone between the rural and urban areas due to their role in improving the living standards because the suburban area functions as a centre for trade and business (The Second National Urbanisation Policy, 2016). This is supported by McGee (1991) where the suburban area is a complex entity going through a very strong mix between agriculture and industry that can improve the living standards of society towards a better and prosperous condition.

\section{Rural Urban Transformation Constructs}

The process of determining the constructs of this study was formed using two methods which were developed by themselves and selected based on the constructs of previous studies. These constructs were then used to form a set of rural urban transformation indicators for housing.

\section{Housing}

Malaysia has witnessed the growth of the mega urban regions rising and spreading from major cities scattered to the suburban areas including the villages and housings and even the forest areas have also been explored as reconstruction areas (Abdul Samad, Shaharudin, Abdul Hadi, \& Ahmad Fariz 2008; McGee, 1991). The expansion of housing area took place dramatically especially after the New Economic Policy (NEP) was launched (Shaharudin, Abdul Samad, Ruslan and Abdul Hadi, 2016) and residential areas were used as an indicator to development with human life as a residence. In fact, according to Shaharudin, Abdul Samad, Abdul Hadi and Ahmad Fariz (2008), the facilities available around residential areas become the focus of the residents and visitors such as recreational park which is a place for social interaction in fostering racial unity in Malaysia.

Back to the housing aspect, Haryati and Nurasyikin (2013) describe the well-being of the residents for this indicator includes place of residence, health facilities, nutrition and the 
INTERNATIONAL JOURNAL OF ACADEMIC RESEARCH IN BUSINESS AND SOCIAL SCIENCES Vol. 8, No. 8, August 2018, E-ISSN: 2222-6990 @ 2018 HRMARS

environment that influence one's life. The main approach seen on the population as a result of the transformation process is in terms of social environment, lifestyle and surrounding condition. As for domestic and foreign manufacturers, they built factories and housings near the city's core to reduce the cost of land. In addition, Bing-Sheng (2016) explains that the manufacturing industry needs a large labour force and the area near the city's core has a high population density and is saturated. Following the development of the manufacturing industry, many residents are indirectly attracted to reside in the suburban area as there are many housing sites built and working in the core area. A house and its surrounding is one of the basic necessities and it influences the well-being of life.

For this study, researcher has adopted the housing indicators to examine the well-being of suburban residents as according to Shaharudin et al. (2016), housing development is closely linked to the transformation process in Malaysia. Molly O'Meara, Kai and Peter (2007) explained that in 2008, more than 50 million people worldwide had moved to urban and suburban areas each year. This argument was strengthened when McGee (2009) revealed that statistically, many residents began to break the city boundaries and continue to expand to the fringe areas resulting in the increase in the housing density along with the addition of various functions and safety facilities. The existence of rapidly growing housing estates, especially since the late 1980s, is to support the well-being of the population has been increasing each year (Shaharudin et al., 2016). For example in Seremban in 1981, the population was estimated to be less than 3,000 people and in 2009, the population was estimated to be 397,000 people (Seremban Municipal Council website, 2009). By 2020, the population is estimated to be 594,000 people (Malaysia, 2000). As a result, the Seremban suburban area has become the area developed for housing development purposes. Without own home, one may feel that life is incomplete and an insecure future.

The housing aspect examined in this study refers to (Abdul Rahman, 2011; Katiman 2006a; Shaharudin et al., 2016 and Mohamad Sofiyuddin, Abdul Samad, Shaharudin, and Syazwani, 2016) by looking at the tendency of area selection, environmental security and facilities provided. The existence of the rapidly growing housing estates, especially since the late 1980s, is to support the population growth which has been increasing each year (Shaharudin et al., 2016). According to Nurasyikin and Haryati (2013), in addition to the aspects of bedrooms and property ownership as well as home appliances, people tend to choose a housing area with a proper security control such as patrols from the authorities or a residents' association to ensure a secured surrounding. This situation ensures that the household is in a comfortable condition. He added that the development of proper facilities in a particular area will definitely result in an increase in population income. This situation, at the same time, causes the rate of selection of an area to increase and can, in fact, be used as an indicator of population well-being. In terms of economy, social and physical, the EMR Klang -Langat Valley suburban zone seems dynamic as the area is undergoing changes especially in the modernisation and urbanisation of small towns, traditional village settlements, organised villages and new villages linked by a good transportation system with the Kuala Lumpur city (Katiman et al., 2010;Yazid, Mohmadisa, Hanifah, \& Nasir, 2017). These changes have resulted in many residents to settle in the suburban area due to attractive job offers and attractive residential properties. This trend is proven by Katiman, (2006a) that many new growth areas are being built in metropolitan suburban areas, particularly housing. Referring to housing ownership, most households have their own homes while only a small number of unmarried individuals who are still lodging. 
INTERNATIONAL JOURNAL OF ACADEMIC RESEARCH IN BUSINESS AND SOCIAL SCIENCES

Vol. 8, No. 8, August 2018, E-ISSN: 2222-6990 @ 2018 HRMARS

\section{Methodology}

This study applied quantitative research design using questionnaire as a research instrument. The selection of this quantitative method was because it involved a large number of, wider and more comprehensive respondents.

\section{Population and Samples}

The study population involved the residents from 15 suburban areas around EMR Klang -Langat Valley, as according to Katiman (2006b), namely Semenyih, Beranang, Mantin, Nilai, Salak Tinggi, Dengkil, Banting, Telok Panglima Garang, Kuala Selangor, Bukit Beruntung, Serendah, Batang Kali, Rasa, Kuala Kubu Bharu and Hulu Bernam. Based on the population census data released in 2010, the total population of the fifteen study areas was 548,424 . Of the total number, this study set a sample size of 1000 people, applied in order to meet the sample size requirement by (Comrey \& Lee, 1992; Meyers et al., 2006). However, in this study, researchers used a sample size of 1015 persons, which is 15 more than the proposed sample as the number of samples will decrease after going through item and sample removal process in the Exploratory Factor Analysis (EFA) and Confirmatory Factor Analysis (CFA). The selected respondents were the heads of the household.

Table 1: Number of respondents by area

\begin{tabular}{llccc}
\hline NO & AREA & $\begin{array}{c}\text { Number of } \\
\text { Residents } \\
\text { (Person) }\end{array}$ & $\begin{array}{c}\text { Number of } \\
\text { Samples } \\
\text { (Person) }\end{array}$ & $\begin{array}{c}\text { Percentage } \\
\text { (\%) }\end{array}$ \\
\hline 1. & Semenyih & 49,076 & 90 & 9 \\
2. & Beranang & 163,560 & 299 & 29.8 \\
3. & Mantin & 25,341 & 47 & 4.8 \\
4. & Nilai & 38,612 & 71 & 7.0 \\
5. & Salak Tinggi & 21764 & 41 & 4.0 \\
6. & Dengkil & 6066 & 12 & 1.0 \\
7. & Banting & 26062 & 49 & 4.8 \\
8. & Telok Panglima Garang & 6504 & 13 & 1.0 \\
9. & Kuala Selangor & 11649 & 22 & 2.3 \\
10. & Bukit Beruntung & 40877 & 76 & 7.5 \\
11. & Serendah & 83099 & 152 & 6.0 \\
12. & Batang Kali & 32783 & 61 & 0.5 \\
13. & Rasa & 2999 & 7 & 2.5 \\
14. & Kuala Kubu Bharu & 13361 & 25 & 4.8 \\
15. & Hulu Bernam & 26671 & 50 & $\mathbf{1 0 0}$ \\
\hline
\end{tabular}




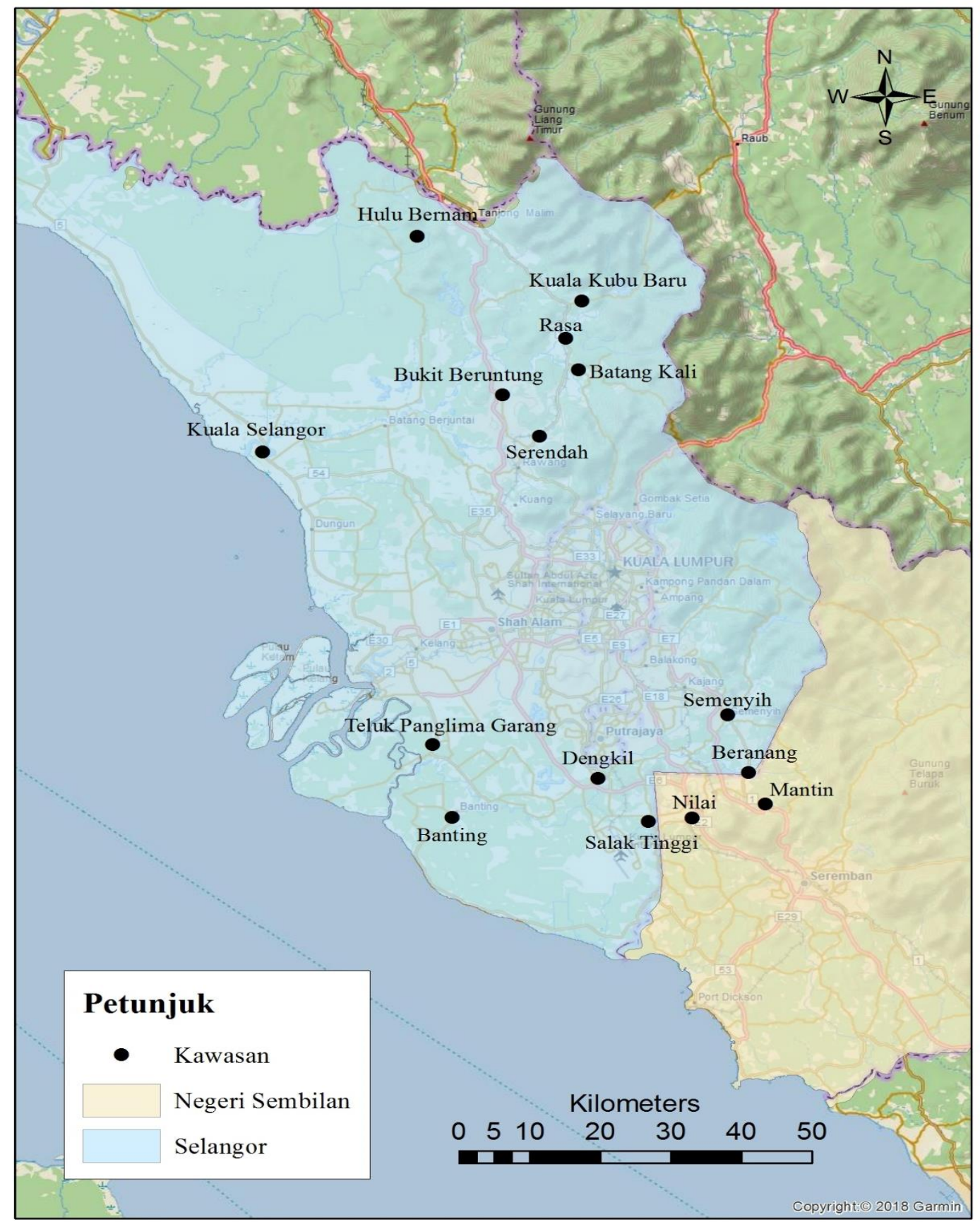

Figure 1: Peri urban area of Klang-Langat valley extended metropolitan region

\section{Study Instruments}

This study is a survey research by using a questionnaire instrument. The selection of this method of instrument involved a large number of, and comprehensive respondents (Ary, Jacobs \& Asghar, 2002). In this context, the questionnaire survey method was chosen to gather data pertaining to housing constructs. The research instrument built was consisted of two parts, namely respondents' background and housing constructs. The item measurement scale for each variable was by using the 
INTERNATIONAL JOURNAL OF ACADEMIC RESEARCH IN BUSINESS AND SOCIAL SCIENCES Vol. 8, No. 8, August 2018, E-ISSN: 2222-6990 @ 2018 HRMARS

5-point Likert scale where 1=Strongly disagree, 2=Disagree, 3=Neutral, 4=Agree and 5=Strongly agree.

Table 2: Questionnaire's items and item questions

\begin{tabular}{cl}
\hline Item & Item question \\
\hline B1_1 & I chose to stay in this area as it was far from the hustle and bustle of the city. \\
B1_2 & I chose to stay in this area because of its proximity to the workplace. \\
B1_3 & I chose to stay in this area because there was a primary school. \\
B1_4 & I chose to stay in this area because there is a high school here. \\
B1_5 & I choose to stay in this area as it is close to family members/relatives. \\
B1_6 & Security forces such as police and RELA patrol every night to reduce crime \\
B1_7 & I feel safe to live here because of the low number of criminal case. \\
B1_8 & High security escort is my main choice to settle here. \\
B1_9 & This home is my choice to stay here. \\
B1_10 & I settled here because the house of worship is just nearby. \\
B1_11 & I choose to live in this area because the price offered for the house is \\
B1_12 & The neighbourhood here assures safety. \\
B1_13 & The housing in my area is equipped with indoor hall facilities. \\
B1_14 & The housing in my area is equipped with playground facilities. \\
B1_15 & Leisure facilities in the residential area are utilised by me and family members. \\
B1_16 & My residential area is equipped with service facilities such as 1Malaysia Clinic. \\
B1_17 & Lots of nearby sundry shops around my home area. \\
B1_18 & Many hypermarkets are nearby surrounding my home area.
\end{tabular}

Table 3: Research Instrument

\begin{tabular}{cccc}
\hline Construct & Sub-construct & $\begin{array}{c}\text { Number } \\
\text { of Items }\end{array}$ & Source of Item \\
\hline Housing & Facilities & 7 items & Built by researchers and \\
& Area selection & 6 items & constructed with modified \\
& Security & 5 items & $\begin{array}{l}\text { references of (Abdul Samad et } \\
\text { al., 2008), (Mohd Yusof and } \\
\end{array}$ \\
& & Mohamad Lukman, 2002) and \\
& & (Nurasyikin, 2013) \\
\hline
\end{tabular}

\section{Data Analysis Methods}

The data used in this study were analysed using the Statistical Package for the Social Sciences (SPSS) version 22.0 and AMOS version 20.0. The data analysis involved two stages. The first stage conducted was to analyse the reliability. This analysis was performed on each variable to examine the level of reliability of the data obtained. The second analysis involved the exploratory factor analysis on the items in the study to see how the items used were classified according to certain factors (Hair, Black, Babin, Anderson, \& Tatham, 2010). 
INTERNATIONAL JOURNAL OF ACADEMIC RESEARCH IN BUSINESS AND SOCIAL SCIENCES

Vol. 8, No. 8, August 2018, E-ISSN: 2222-6990 @ 2018 HRMARS

\section{Internal reliability analysis}

Prior to testing the relationship significance of the structural model, the measurement model needs to have a satisfactory level of validity and reliability (Fornell \& Larcker, 1981). According to Sekaran and Bougie (2009), the higher the value of the Cronbach's Alpha coefficient, the higher the internal reliability. Referring to Table 4, the reliability with the Cronbach's Alpha value for the whole items is greater than 0.7 .

Table 4: Internal reliability values of the study questionnaire

\begin{tabular}{llll}
\hline Part & Variable & Number of Items & $\begin{array}{l}\text { Cronbach's } \\
\text { value }\end{array}$ \\
\hline \multirow{3}{*}{ Housing } & Facilities & 7 & 0.824 \\
& Area selection & 6 & 0.795 \\
& Security & 5 & 0.766 \\
\hline
\end{tabular}

\section{Factor Analysis}

Factor analysis is a statistical approach used to identify, reduce and restructure a large number of questionnaire items into specific constructs, under specific variables. Factor analysis is a statistical approach used to summarise the information contained in some of the original variables to smaller or general dimensions into certain constructs (Chua, 2014). The approaches for factor analysis can be fundamentally grouped into two different approaches which are exploratory analysis and confirmatory analysis.

The theme used in this factor analysis is factor loading that gives information on to what extent a factor determines the test score built by comparing it with other measurements. If comparisons are made with other measurements that measure the same constructs, a high factor loading gives evidence of convergent validity while if comparisons are made with other measurements that measure different constructs, a moderate and low factor loading will provide evidence of differential validity of the construct validity (Cohen, Manion \& Morrison, 2000).

\section{Exploratory Factor Analysis}

The following is the result of the construct purification process based on EFA and the reliability test performed on the pre-test data of the study. The construct purification analysis was conducted on the study variables which was housing. The purpose of this EFA analysis was to identify and restructure a large number of questionnaire items into components under specific particular variables from the study samples which really represented the study variables (Hair et al., 2010). The factor structure formed was based on feedback findings from the study samples.

Several steps and procedures have been implemented to conduct the EFA as suggested by (Sekaran \& Bougie, 2016; Hair, Black, Babin, Anderson, \& Tatham, 2006; Comrey \& Lee, 1992). Refer to goodness-of-fit for EFA procedures as shown in Table 5. 
INTERNATIONAL JOURNAL OF ACADEMIC RESEARCH IN BUSINESS AND SOCIAL SCIENCES

Vol. 8, No. 8, August 2018, E-ISSN: 2222-6990 @ 2018 HRMARS

Table 5: Goodness-of-fit

\begin{tabular}{lc}
\hline Goodness-of-fit Exploratory Analysis Factor (EFA) \\
\hline Exploratory Factor Analysis (EFA) Model Index \\
Barlett's Test of Sphericity/x $\mathbf{x}^{2}$ (sig. <0.005) & Proposed value \\
Keiser-Meyer-Olkin (KMO) sample adequacy test & $<0.05$ \\
Factor loadings value & $>0.06$ \\
Communalities value & $\geq 0.40$ \\
Eigen value & $\geq 0.30$ \\
Variance percentage change value & $\geq 1.00$ \\
\% of variance contribution towards factor & $\geq 8.00$ \\
\hline Source : (Hair et al., 2006; Tabachnick \& Fidell, 1996; Sekaran \& Bougie, $2016 ;$ Comrey \&
\end{tabular}
Lee, 1992).

The above procedure was repeatedly performed until constructs with their own items were formed. This procedure involved several item iterations until the desired construct with its own item was finally formed.

\section{Study Findings}

\section{Factor Analysis of Housing Variables}

The result of the Exploratory Factor Analysis (EFA) on the transformation indicator, which is housing, describes that the anti-image correlation analysis procedure shows a correlation value of more than 0.5 and this illustrates that the factor analysis can be further continued. The sampling adequacy measure of KaiserMeyer-Olkin (KMO) and Barlett's Test of Sphericity obtained shows that the value of KMO is 0.891 while Barlett's Test of Sphericity test is significant with the value of Chi-Square 3095.606 with 153 degrees of freedom. Refer to Table 6.

Table 6: Suitability Test on the Use of Factor Analysis and KMO Item Uniformity and Barlett's Test on Housing Variables

\begin{tabular}{lll}
\hline Kaiser-Meyer-Olkin & Measure of Sampling & 0.909 \\
& Adequacy & \\
\hline Barlett's Test of Sphericity & Approx. Chi-Square & 6498.061 \\
& df & 153 \\
& Sig. & .000 \\
\hline
\end{tabular}

The factor analysis was performed by the researcher determining the number of factors to be extracted into three as categorised. Table 7 shows the component matrix with varimax rotation. The varimax rotation method was performed as it reduced the number of complex variables and increased the expected yield. The results show that items B1_1, B1_5 and B1_16 have been dropped for having an anti-image correlation matrix value of less than 0.5. While the values ofB1_9, B1_13, B1_14, B1_15, B1_17 and B1_18 belong to component 1 which is facilities; B1_6, B1_7,B1_8, B1_10 and B1_12 belong to component 2 which is security and component 3 which is area selection are B1_2, B1_3 and B1_4. The values shown in Table 7 are the coefficients or the factor loadings for each item that tends to each factor. These values show the correlation formed between the items and the factors and it is the key to understanding the nature of these factors. 
INTERNATIONAL JOURNAL OF ACADEMIC RESEARCH IN BUSINESS AND SOCIAL SCIENCES Vol. 8, No. 8, August 2018, E-ISSN: 2222-6990 @ 2018 HRMARS

Table 7: Component Matrix with Varimax Rotation of Housing Variables

\begin{tabular}{llll}
\hline & Component & & \\
\cline { 2 - 4 } Item & Facilities & Security & \\
\hline B1_9 & 0.604 & & \\
B1_13 & 0.654 & & \\
B1_14 & 0.606 & & \\
B1_15 & 0.699 & & \\
B1_17 & 0.621 & & \\
B1_18 & 0.663 & & \\
\hline B1_6 & & & \\
B1_7 & & 0.553 & \\
B1_8 & 0.642 & \\
B1_10 & 0.707 & \\
B1_12 & 0.615 & 0.531 \\
\hline B1_2 & 0.617 & 0.873 \\
B1_3 & & 0.788 \\
B1_4 & & \\
\hline
\end{tabular}




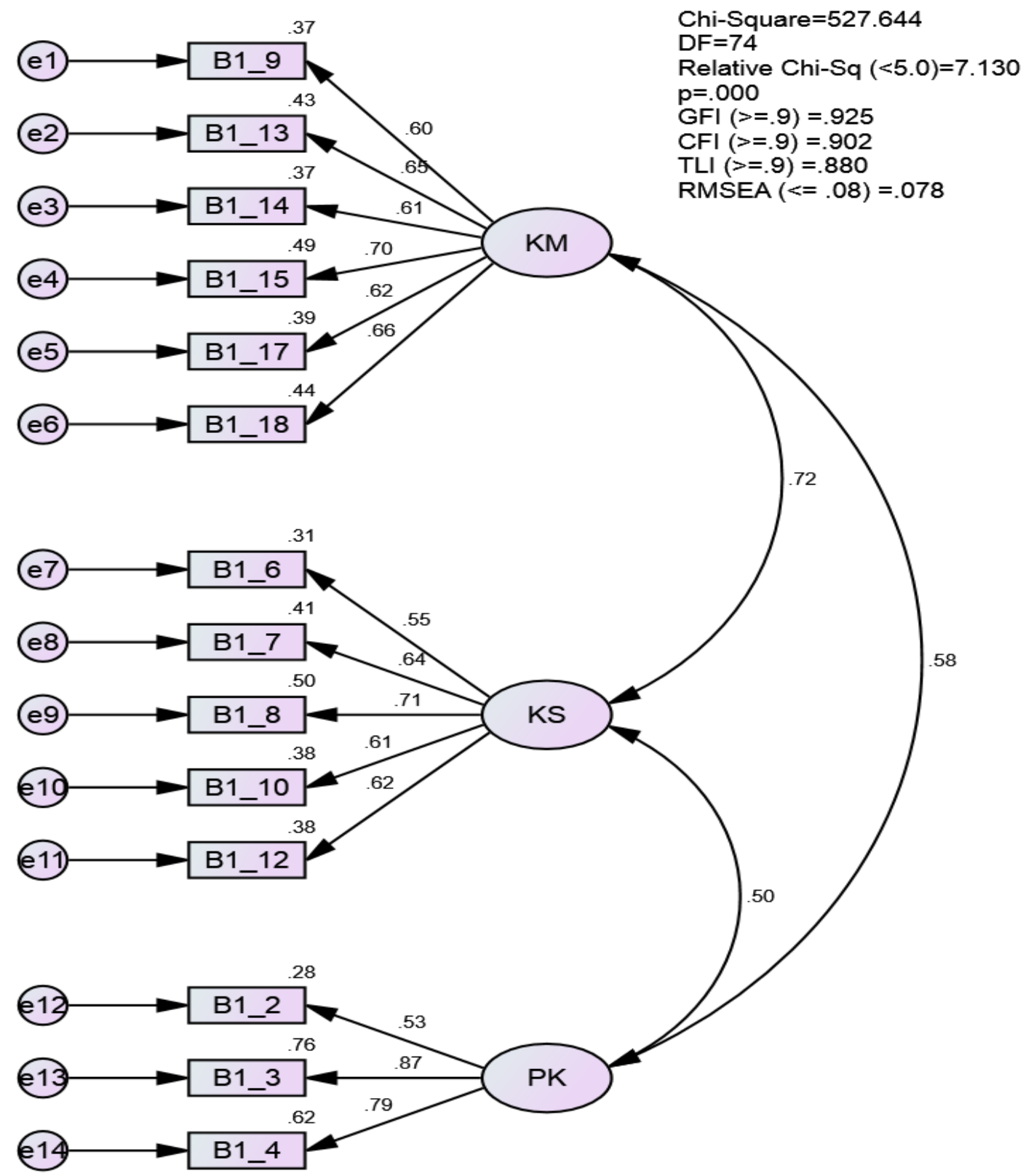

Legend:

KM: Facilities

KS: Security

PK: Area selection

Figure 2: Factor Analysis on Housing Contructs

\section{Confirmatory Factor Analysis of Housing}

The Exploratory Factor Analysis of Housing involves the fit of a one-factor congeneric model, second order confirmatory factor analysis model of housing and the housing study construct validity assessment. 
INTERNATIONAL JOURNAL OF ACADEMIC RESEARCH IN BUSINESS AND SOCIAL SCIENCES

Vol. 8, No. 8, August 2018, E-ISSN: 2222-6990 @ 2018 HRMARS

\section{Fit Evaluation of the One-Factor Congeneric Model}

The index modification process was conducted on the CFA one-factor congeneric model for three housing dimensions, namely facilities, area selection and security. Table 8 shows the accuracy value of the one-factor congeneric model of housing. The findings show that each dimension meets the acceptable indicator value.

Table 8: Fit Accuracy of One-factor Congeneric Model for Housing

\begin{tabular}{|c|c|c|c|c|c|c|c|c|}
\hline $\begin{array}{l}\text { Value of } \\
\text { Acceptable } \\
\text { Indicator/ } \\
\text { Dimension }\end{array}$ & CMIN & DF & $\begin{array}{l}\text { CMIN/DF } \\
<5\end{array}$ & $\begin{array}{l}\text { PROB } \\
\text { (p-value) } \\
>0.05\end{array}$ & $\begin{array}{l}\text { GFI } \\
>0.09\end{array}$ & $\begin{array}{l}\mathrm{CFI} \\
>0.09\end{array}$ & $\begin{array}{l}\text { TLI } \\
>0.09\end{array}$ & $\begin{array}{l}\text { RMSEA } \\
<0.08\end{array}$ \\
\hline Facilities & 9.211 & 3 & 3.070 & .027 & .995 & .993 & .986 & .46 \\
\hline $\begin{array}{l}\text { Area } \\
\text { Selection }\end{array}$ & .000 & 0 & 0.000 & .000 & 1.000 & .1 .000 & .000 & .000 \\
\hline Security & 7.642 & 1 & 7.642 & .006 & .995 & .987 & .961 & .082 \\
\hline
\end{tabular}

In this modification process, some items have been removed. Two items were removed from the facilities dimension, namely B1_9 and B1_18. As for the area selection dimension, the items removed was B1_2, while for the security dimension two items were removed, namely B1_10 and B1_12.

\section{Second Order of Housing Confirmatory Factor Analysis Model}

Figure 2 shows the second order CFA model of housing constructs that have achieved good fit accuracy. This model is a combination of all dimensions of housing constructs maintained in the first order analysis. 
INTERNATIONAL JOURNAL OF ACADEMIC RESEARCH IN BUSINESS AND SOCIAL SCIENCES Vol. 8, No. 8, August 2018, E-ISSN: 2222-6990 @ 2018 HRMARS

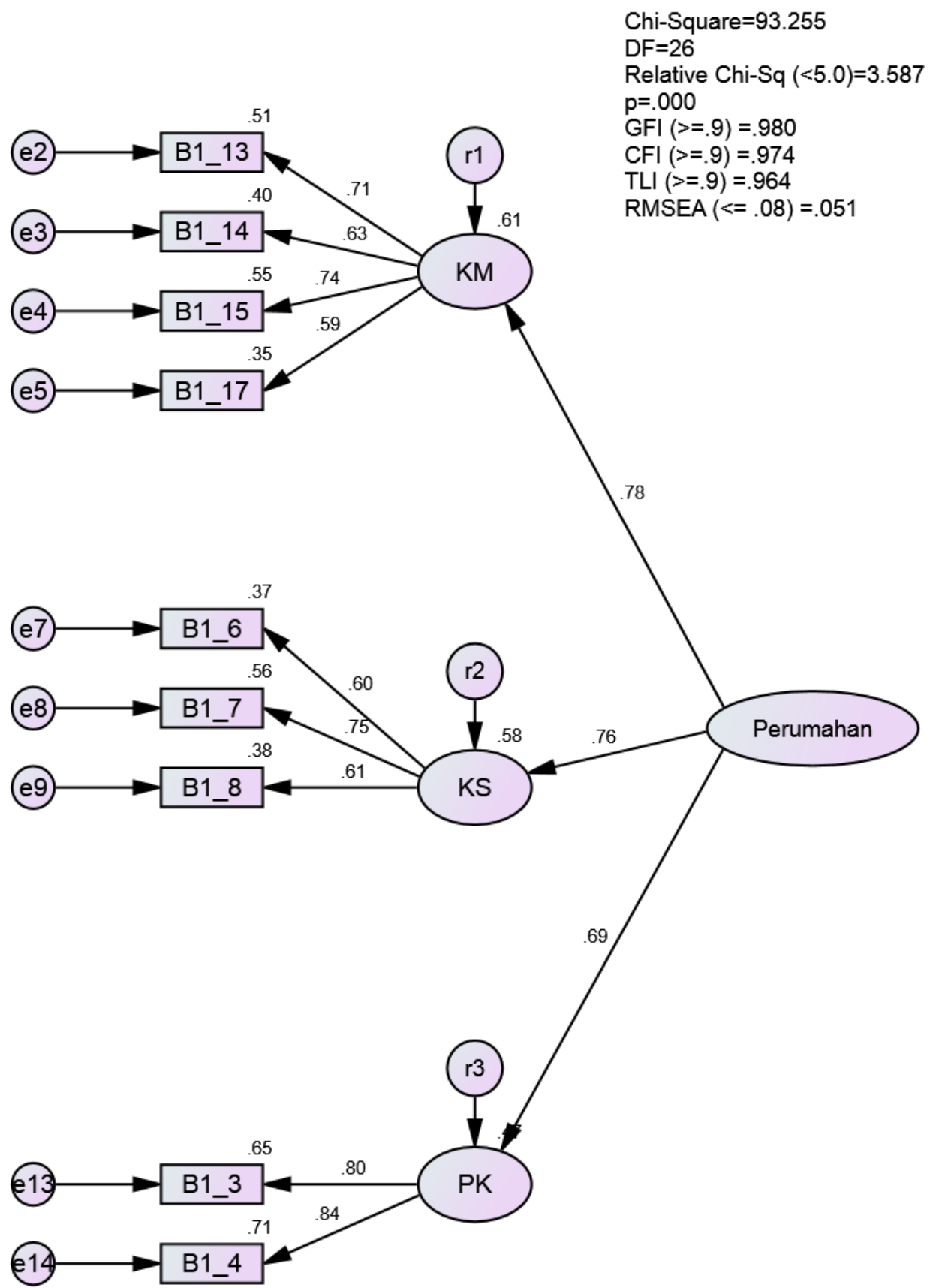

\section{Legend:}

KM: Facilities

KS: Security

PK: Area selection

Figure 3: Second Order Confirmatory Factor Analysis Model of Housing

The model analysis in Table 9 shows that the model formed has reached a goodness of fit level based on the specified indicators $(C M I N=93.255, \mathrm{DF}=26, \mathrm{CMIN} / \mathrm{DF}=3.587, \mathrm{p}=.000, \mathrm{GFI}=.980, \mathrm{CFI}=.974$, $\mathrm{TLI}=.964$ and RMSEA $=.051)$. 
INTERNATIONAL JOURNAL OF ACADEMIC RESEARCH IN BUSINESS AND SOCIAL SCIENCES Vol. 8, No. 8, August 2018, E-ISSN: 2222-6990 @ 2018 HRMARS

Table 9: Fit Model Indicators of Second Order Confirmatory Factor Analysis of Housing Contructs

\begin{tabular}{lll}
\hline Indicator & Acceptable Indicator Value & $\begin{array}{l}\text { Second Order Confirmatory } \\
\text { Factor Analysis }\end{array}$ \\
\hline Absolute Fit Indices & \\
CMIN & & 93.255 \\
DF & $<26$ \\
CMIN/DF & $>.5$ & 3.587 \\
PROB (P-val) & $>0.05$ & .000 \\
RMSEA & $<0.08$ & .051 \\
Goodness of Fit Index (GFI) & $>0.90$ & .980 \\
Comparative Fit Index (CFI) & $>0.90$ & .974 \\
Tucker-Lewis Indices (TFI) & $>0.90$ & .964 \\
\hline
\end{tabular}

\section{Construct Validity Assessment}

Table 10 shows the weighting factor of factor loading $(\lambda)$ for the items retained for the dimensions exceeding the specified values of weighting factor which is 0.5 . The weighting factor values for facilities dimension are between 0.590 and 0.747 , area selection dimension are between 0.829 and 0.835 , and security dimension are between 0.599 and 0.765 .

The values of Average Variance Extracted (AVE) for each dimension must reach AVE $\geq .4$ (Hair et al., 2010). As for the facilities dimension (AVE = 0.44), area selection dimension (AVE $=0.69$ ) and safety dimension $(A V E=0.44)$. While for composite reliability $(C R)$ indicators, all three dimensions reached a good value of more than 0.7 . This shows that all three dimensions and items contained in the CFA measurement model have convergent validity.

Table 10: Descriptive Statistics and Validity of Housing Constructs

\begin{tabular}{lcclcc}
\hline \multirow{2}{*}{ Dimension } & Item & $\lambda$ & SMC & AVE & CR \\
\hline Facilities & B1_13 & .679 & 0.461041 & & \\
& B1_14 & .629 & 0.395641 & 0.44 & 0.76 \\
& B1_15 & .747 & 0.558009 & & \\
& B1_17 & .590 & 0.3481 & & \\
Area & & & & & \\
selection & B1_3 & .835 & 0.697225 & 0.69 & \\
Security & B1_4 & .829 & 0.687241 & & \\
& & & & & \\
& B1_6 & .599 & 0.358801 & & \\
& B1_7 & .765 & 0.585225 & 0.44 & \\
\hline
\end{tabular}

Note:

$\lambda=$ factor loading

SMC = Squared Multiple Correlations

AVE = Average Variance Extracted

$\mathrm{CR} \quad=$ Composite Reliability 
INTERNATIONAL JOURNAL OF ACADEMIC RESEARCH IN BUSINESS AND SOCIAL SCIENCES

Vol. 8, No. 8, August 2018, E-ISSN: 2222-6990 @ 2018 HRMARS

\section{Discussion}

This study was conducted to assess the reliability and validity of housing constructs using both exploratory factor analysis (EFA) and confirmatory factor analysis (CFA) in the context of suburban area. The results of the study through the EFA and CFA processes showed that only three subconstructs of the housing constructs had high reliability and validity values. Among the sub-constructs of housing were facilities (KM), area selection (PK) and security (KS).

Homes and the surrounding environment are basic necessities that affect the well-being of life. The results showed that all three sub-constructs were suitable to be applied for measuring the well-being of the housing constructs in the suburban area. The sub-constructs formed were parallel with the sub-constructs proposed by (Economic Planning Unit 1999, 2002; Abdul Rahman, 2011; Katiman 2006a; Shaharudin et al., 2016; Mohamad Sofiyuddin et al., 2016) through the conditions of area selection and surrounding security. In fact, according to Shaharudin et al. (2008), the facilities available around a residential area are the focus of the residents and visitors, such as recreational park which is a place for social interaction to foster racial unity in Malaysia. Elements such as the selection of settlement and residential area, facilities and security enable the expansion of the area and cause transformation to occur rapidly, leading to the development of speculation and future investments.

Housing demonstrates a visible physical structure and is known as a place of residence for an individual and families. In addition, it also functions as a place of protection for humans from all threats and dangers. Basic facilities such as shops and markets, schools, kindergartens, nurseries and clinics provided are important because the absence of these facilities will cause family activities to be affected and may result in a waste of time and energy (Nurizan, 1998). Apart from facilities, the other aspects that support housing are area selection and security. Katiman et al. (2011) has applied facilities sub-construct to see the community's tendency to choose a residential area. This is because with the basic facilities, the degree of comfort of the population will increase. He added that residential homes were one of the basic needs of the population. Therefore, the surrounding security and area selection factors are the basic characteristics in forming a happy family for future assurance.

\section{Conclusion}

The current drastic and rapidly growing development constraints may trigger implications on humans and the surrounding environment. The destruction occurred is undoubtedly inevitable in order to meet the demands of growth and development in fulfiling human desires to survive the daily life. In order to ensure that any future planning and implementation of a development work in tandem with the needs of human well-being, the cooperation of all agencies and administrative coordination are crucially required. As for the context of transformation of suburban area in this study, this situation is seen to focus on suburban changes towards betterment for investment as well as attractive residential areas by enjoying all the basic infrastructure facilities and quality social services. This situation illustrates that in addition to growing spaces, it is at least necessary to have efficient basic goods and services to help improve the rural urban populations living in the surrounding area.

Overall, the progress in the housing aspect has shown a positive growth for the suburban area development in ensuring the well-being of the people. Therefore, the role of housing facilities and security in a development needs to be taken seriously as development in the housing sector is the backbone of a greater city via the rural-urban interaction process. In the general view, a quality life certainly requires constant effort in ensuring the well-being of housing, physical environment and 
INTERNATIONAL JOURNAL OF ACADEMIC RESEARCH IN BUSINESS AND SOCIAL SCIENCES

Vol. 8, No. 8, August 2018, E-ISSN: 2222-6990 @ 2018 HRMARS

social activity to reduce the impact on the increase of social issues from continuously spreading such as crime and theft (Samruhaizad \& Azahan, 2014). This situation is evidently in line with that of Azahan, Abdul Hadi and Kadaruddin (2008) where individuals in the suburban areas play an important role in creating and embracing urban environment to shape their own well-being. This means that humans will do a variety of adaptations towards the environment so that the environment is in line with human instincts. However, this study can still be improved in the future by taking into account other aspects that drive the well-being of the population in the suburban area based on the demographic and background factors of the residents. In conclusion, this study was conducted to analyse and build a model for the well-being of the suburban populations, for the housing constructs with high reliability and validity so that the study results obtained are of good quality.

\section{Acknowledgement}

The discussion in this article is part of the findings of the research entitled 'The Development of the Indicators for Rural Urban Transformation at the Peri Urban Areas of Klang-Langat Valley Extended Metropolitan Region' sponsored by the Ministry of Higher Education Top-down Grant 2016 (20160238-106-41).

Corresponding Author

Yazid Saleh, PhD

Department of Geography \& Environment,

Faculty of Human Sciences, Sultan Idris Education University, 35900 Tanjong Malim, Perak, Malaysia.

Email: yazid@fsk.upsi.edu.my

\section{References}

Abdul Rahman, E. (2011). Pembandaran dan Kehidupan Bandar di Semenanjung Malaysia. Akademika, 81(2), 23-39.

Abdul Samad, H., Shaharudin, I., Abdul Hadi, H. S., \& Ahmad Fariz, M. (2008). Dayahuni bandar (urban livability). Bangi: LESTARI, Universiti Kebangsaan Malaysia.

Ary, D., Jacobs, L. C., \& Asghar, R. (2002). Introduction to Research in Education (6th ed.). Belmont: Wadsworth.

Azahan, A., Abdul Hadi, H. S., \& Kadaruddin, A. (2008). Penilaian makna kualiti hidup dan aplikasinya dalam bidang pengurusan persekitaran di Malaysia. Akademika, 72(1), 45-68.

Christiaensen, L., Weerdt, J., \& Todo, Y. (2013). Urbanization and poverty reduction: The role of rural diversification and secondary towns. Agricultural Economics, 44(4-5), 435-447.

Chua, Y. P. (2014). Kaedah dan statistik penyelidikan (3rd ed.). Malaysia: Mc. Graw Hill Sdn Bhd.

Cohen, L., Manion, L., \& Morrison, K. (2000). Research methods in education (5th ed.). London: RoutledgeFalmer.

Comrey, A. L., \& Lee, H. B. (1992). A first course in factor analysis (2nd ed.). Hillsdale, New Jersey: Lawrence Erlbaum Associates.

Dasar Perbandaran Negara Kedua. (2016). Kementerian perumahan dan kerajaan tempatan. Malaysia.

Fornell, C., \& Larcker, D. (1981). Evaluating structural equation models with unobservable variables and measurement error. Journal of Marketing Research, 18(1), 39-50.

Friedman, F., \& Wulff, R. (1986). Perubahan bandar: kajian perbandingan masyarakat perindustrian 
INTERNATIONAL JOURNAL OF ACADEMIC RESEARCH IN BUSINESS AND SOCIAL SCIENCES

Vol. 8, No. 8, August 2018, E-ISSN: 2222-6990 @ 2018 HRMARS

yang baru. Kuala Lumpur: Dewan Bahasa dan Pustaka.

Hair, J. F., Black, B., Babin, B. J., Anderson, R. E., \& Tatham, R. L. (2010). Multivariate data analysis: A global perspective. New Jersey: Pearson Education.

Hair, J. F., Black, W. C., Babin, B. J., Anderson, R. E., \& Tatham, R. L. (2006). Multivariate Data Analysis (6th ed.). New Jersey: Prentice Hall.

Haryati, S., \& Nurasyikin, M. (2013). Transformasi dan pembangunan luar bandar: Kesan ke atas penduduk dan persekitaran. International Journal of the Malay World and Civilisation(IMAN), 1(2), 71-81.

Jones, G. W. (2014). Urbanisation and development in south-east Asia. Malaysian Journal of Economic Studies, 51(1), 103-120.

Katiman, R. (2006a). Migrasi ke kawasan pinggiran Wilayah Metropolitan Lembah Klang. Akademika, 68, 3-27. Retrieved from http://myais.fsktm.um.edu.my/8593/

Katiman, R. (2006b). Pembandaran dan perkembangan wilayah metropolitan lanjutan Lembah KlangLangat, Malaysia. Jurnal E-Bangi, 1(1), 1-27.

Katiman, R., Abdul Rahim, M. N., Er, A. C., Aishah@Eshah, M., Zaini, S., Mohd Hasan, N., \& Rosniza, A. (2011). Impak pembangunan Bandar Baru Nusajaya Wilayah Iskandar Malaysia terhadap kesejahteraan hidup penduduk asal setempat. Geografia: Malaysian Journal of Society and Space, 7(5), 14-28.

Katiman, R., Mochamad, R., Choy, E. A., Abdul Rahim, M. N., Zaini, S., \& Norazuan, Md. H. Aishah@Esah, H. M. (2010). Pembandaran dan rebakan bandar di pinggir Wilayah Metropolitan Klang-Langat. GEOGRAFIA OnlineTM Malaysian Journal of Society and Space, 6(2), 37-50.

Malaysia. (2000). Banci penduduk dan perumahan negara. Kuala Lumpur: Jabatan Perdana Menteri. McGee, T. G. (1991). The emergence of desakota regions in Asia: Expanding a hypothesis. The Extended Metropolis: Settlement Transition in Asia, 3-25.

McGee, T. G. (2009). The spatiality of urbanization: The policy challenges of Mega-Urban and Desakota regions of Southeast Asia. Japan.

Meyers, L. S., Gamst, G., \& Guarino, A. J. (2006). Applied multivariate research: Design and interpretation. Sage Publications.

Mohamad Sofiyuddin, S., Abdul Samad, H., Shaharudin, I., \& Syazwani, A. (2016). Dayahuni perumahan dalam pembangunan bandar lestari. In S. Yazid, H. Mohmadisa, N. Nasir, \& C. N. Mohamad Suhaily Yusri (Eds.), Permbandaran dan Transformasi Ruang di Malaysia (pp. 83-94). Universiti Pendidikan Sultan Idris.

Mohd Yusof, H., \& Mohamad Lukman, Z. (2002). Pembangunan bandar mapan dan kualiti hidup masayarakat: Penelitian sepintas lalu. In Dalam Impak Pembangunan Kualiti Hidup dan Persekitaran. Kuala Lumpur: Utusan Publications \& Distributors Sdn. Bhd.

Molly O'Meara, S., Kai, L., \& Peter, N. (2007). State of the World. Our Urban Future. London: Earthscan.

Nurasyikin, M. (2013). Transformasi Pekan Parit Raja: Kajian terhadap kesejahteraan hidup masyarakat. Universiti Tun Hussein Onn Malaysia.

Nurasyikin, M., \& Haryati, S. (2013). Transformasi pembangunan luar bandar: Kesan ke atas kesejahteraan hidup masyarakat. In Persidangan Geografi \& Alam Sekitar, 5-6 Mei 2013. Universiti Pendidikan Sultan Idris, Perak.

Nurizan, Y. (1998). Kualiti perumahan dan kualiti hidup. Analisis, 5(1 \& 2), 133-149.

Samruhaizad, S. (2015). Kesedaran pembangunan, kesediaan diri dan penerimaan perubahan: Komponen meningkatkan kualiti hidup masyarakat pinggir bandar di daerah Hulu Langat, 
INTERNATIONAL JOURNAL OF ACADEMIC RESEARCH IN BUSINESS AND SOCIAL SCIENCES

Vol. 8, No. 8, August 2018, E-ISSN: 2222-6990 @ 2018 HRMARS

Selangor. International Journal of the Malay World and Civilisation, 3(3), 37-121.

Samruhaizad, S., \& Azahan, A. (2014). Isu perbandaran dan kualiti hidup penduduk pinggir bandar. International Journal of the Malay World and Civilisation, 2(1), 63-75.

Sekaran, U., \& Bougie, R. (2009). Research methods for business: A skill building approach (5th ed.). United Kingdom.

Sekaran, U., \& Bougie, R. (2016). Research methods for business: A skill building approach (7th ed.). United Kingdom: John Wiley \& Sons Ltd.

Shaharudin, I., Abdul Samad, H., Abdul Hadi, H. S., \& Ahmad Fariz, M. (2008). Spatial urban metabolism for liveable city. Blueprints for Sustainable Infrastructure Conference. In The New Zealand Society for Sustainability Engineering and Science (NZSSES). Auckland, New Zealand.

Shaharudin, I., Abdul Samad, H., Ruslan, R., \& Abdul Hadi, H. S. (2016). Transformasi dan dayahuni perumahan di Malaysia. In M. J. Jamaluddin, H. Abdul Samad, M. Ahmad Fariz, \& A. Kadaruddin (Eds.), Transformasi dan dayahuni habitat manusia (pp. 157-174). Malaysia: UKM.

Shaharudin, I., Lim, C. S., \& Abdul Samad, H. (2004). Kemudahterancaman (Vulnerability) penduduk terhadap perubahan guna tanah di Selangor. Malaysian Journal of Environmental Management, 5(1), 79-98.

Tabachnick, B. G., \& Fidell, L. S. (1996). Using multivariate statistics (3rd ed.). New York: HarperCollins. Unit Perancangan Ekonomi. (1999). Kualiti hidup Malaysia 1999. Kuala Lumpur: Jabatan Perdana Menteri.

Unit Perancangan Ekonomi. (2002). Kualiti hidup Malaysia 2002. Kuala Lumpur: Jabatan Perdana Menteri.

Wan Maznah, W. H., Rosniza Aznie, C. R., \& Azahan, A. (2016). Pembandaran dan kemudahterancaman isi rumah pinggir bandar raya metropolitan Kuala Lumpur. Geografia: Malaysian Journal of Society and Space, 12(14), 41-49.

Webster, D. (2002). On the Edge: Shaping the future of peri-urban East Asia. Stanford: The Asia/Pacific Research Center, Stanford University.

Yahaya Ibrahim. (2002). Proses industrialisasi luar bandar: Impak terhadap komuniti di Tanah Rancangan Felda. In Z. Mohamad Lukman, J. Abdul Aziz, H. Mohd Yusof, \& Faridatul Azna (Eds.), Impak Pembangunan: Kualiti Hidup dan Persekitaran. Kuala Lumpur: Utusan Pablications \& Distributors Sdn. Bhd.

Yazid, S., Mohmadisa, H., Hanifah, M., \& Nasir, N. (2017). Issues of rural-urban transformation on the fringe of metropolitan region: Several findings from the Selangor Northern Corridor, Malaysia. International Journal of Academic Research in Business and Social Sciences, 7(6), 913-924. 